\title{
Affective Media, Cyberlibertarianism and the New Zealand Internet Party
}

\author{
Olivier Jutel
}

\author{
University of the South Pacific, Suva, Fiji, jutel_o@usp.ac.fj
}

\begin{abstract}
The New Zealand Internet Party tested key notions of affective media politics. Embracing techno-solutionism and the hacker politics of disruption, Kim Dotcom's party attempted to mobilise the youth vote through an irreverent politics of lulz. While an electoral failure, the party's political discourse offers insights into affective media ontology. The social character of affective media creates the political conditions for an antagonistic political discourse. In this case affective identification in the master signifier "The Internet" creates a community of enjoyment, threatened by the enemy of state surveillance as an agent of rapacious jouissance. The Internet Party's politics of lulz was cast as a left-wing techno-fix to democracy, but this rhetoric belied a politics of cyberlibertarianism. Dotcom's political intervention attempted to conflate his private interests as a battle that elevates him to the status of cyberlibertarian super-hero in the mould of Edward Snowden or Julian Assange.
\end{abstract}

Keywords: Affect, Lulz, Trolling, Techno-Democracy, The Alt-Right

\section{Introduction}

From across the political spectrum and in critical scholarly circles, affective media (namely, collaborative Web 2.0 technologies) are seen as a fix for the crisis of democracy. The potential for uninhibited communication, connectivity and creativity offers a new and previously unimaginable emancipatory potential. Affective media practices are held as a transformative form of politics prefiguring the new society. Whether trading in digital currencies, using encrypted message services or conducting virtual general assemblies, this new activism toolkit bypasses traditional control mechanisms. Across both progressive and right-wing social media spaces there is a teleology of open-source democracy that tracks very closely to technofuturist and utopian corporate rhetoric. Transformation is deemed rhizomatic; the Internet enables an affective humanity and "new social practices" which, in a postpolitical twist, "[upend] the ideological divide between individualism and collectivism" (Coleman 2014, 49-50).

This article focuses on the political potential of affective media, considering the emergence of the New Zealand Internet Party (IP) as a concrete intervention of affective media politics. The IP was founded by the pirate capitalist, hacker and the "lulzy" ${ }^{1}$ Internet mogul Kim Dotcom. Dotcom emerged as a political symbol of resistance to John Key's right-wing National Party government (Vance 2013). In 2013, Dotcom was a prominent voice opposing an amendment to the GCSB bill which expanded the Government Communications Security Bureau's powers of

\footnotetext{
1 "Lulz" or "the lulz" is a play on the ubiquitous Internet "LOL". Coleman (2014) describes the lulz as a devotion to the carnivalesque above all else and a key marker of subcultural interiority from 4-Chan to the hacker collective Anonymous.
} 
surveillance (which had previously been used illegally against him). Following the bill's passage, Dotcom formed the IP. Officially designated "party visionary", Dotcom spent almost \$5 million NZD (One News 2015) on the party and made a list-sharing alliance with the radical indigenous leftist Mana Party. The IP positioned itself as the realisation of the Internet's political potential against the Key government's attack on innovation, civil liberties and capitulation to American interests. The party itself was to use the Internet to redefine political participation, energising youthful netizens and the marginalised.

While the IP proved an electoral failure, its discourse offers insights into the political potential and limits of affective media politics. This article draws on the discourse theory of Laclau (2005) and the Lacanian Marxism of Žižek (1997, 2006 and 2008) and Dean (2009, 2010 and 2016) to consider affect as a political logic. The predominant theories of affect in new media contexts privilege a Deleuzian reading of affect as inherently social, connective and productive. This article will argue that affective connectivity draws political subjects into libidinal drives and the inter-subjective dynamics of enjoyment.

Laclau's notion of populism is premised on the affective investment in a name such as "Internet Party" which is accompanied by floating signifiers that affirm identity and enjoyment while dividing the social space between the Internet and its enemies. The IP embodies the dialectic in affective media politics between a self-replicating techno-fetishism and a politics of transgressive enjoyment or "jouissance" (Žižek 1997). The result is the displacement of politics: either into communities pursuing jouissance for its own ends, or into circular techno-fixes which relieve us of "the guilt that we might not be doing our part" (Dean 2009, 37-38). In terms of the IP this manifests itself as faith in the Internet as an ideological and organisational principle, to the politics of jouissance where the movement is bonded in trolling John Key as an overdetermined enemy. Within these contours of techno-fetishism and jouissance, affective media offers no emancipatory shortcuts.

Where affective media does present a radical opening to the political is with the project of cyberlibertarianism (Golumbia 2013). The Internet is conceived as a digital frontier with infinite potential for personal and commercial freedom but for the interference of "paternalistic authoritarian systems" (Dahlberg 2010, 337). Battles for Internet freedom invoke the commons while realising the neo-liberal digital autonomous subject. Cyberlibertarianism offers the left a critique of corporate inauthenticity and alienation, which informs the anarcho-capitalism of the sharing economy and the more radical anti-statism of Bitcoin.

Dotcom's political intervention conflated his own interests with 'the Internet' as an object of affective investment, while he battled the forces that would stifle innovation: the global spying infrastructure and the 'Copyright Cartel'. The key moment in the IP's campaign which captured this logic was the "Moment of Truth" (MOT) spectacle. This carefully stage-managed event enlisted cyberlibertarian heroes Glenn Greenwald, Julian Assange and Edward Snowden to both reveal John Key's corruption and at the same time launch Dotcom's "Skype-killer" Megachat. This hacker-inspired political intervention reveals that behind teleologies of affective connectivity and tech-fetishism there lie libertarian notions of cyberspace which conflate digital freedom with the interests of tech-capital.

\section{The Internet Party}

Before proceeding it is necessary to explain the particular political context that created the IP. While the IP has not had the success of other Internet-inspired parties 
like the Five Star Movement in Italy or the Iceland Pirate Party, it is exemplary of the confluence of libertarian and left-wing discourses in affective media politics. The IP was founded by Kim Dotcom, a former hacker and Internet mogul who gained notoriety for his file-sharing service Megaupload, which hosted movies. Dotcom's story became central to New Zealand politics in 2012 with a dramatic raid on his home by the New Zealand government at the behest of the $\mathrm{FBI}$, who sought his extradition on charges of mass copyright infringement. It was subsequently revealed that Dotcom, who was fast-tracked for residency as an investor, was illegally monitored by New Zealand intelligence officials. Prime Minister Key, as minister of the Government Communications Security Bureau (GCSB), was forced to apologise to Dotcom. With the revelations from Edward Snowden in 2013 and Key's attempts to expand the powers of the GCSB, the Dotcom case became central in politicising New Zealand's involvement in the 'Five Eyes' intelligence alliance.

Dotcom announced the formation of his party in 2014 with an emphasis on "techno-solutionism" (Morozov 2014) that did not betray his class interests. And while the IP's emphasis on innovation and technology would be right at home in the campaign of a neoliberal technocrat, the IP was forced to position itself on the far-left of New Zealand politics. The centre-right Prime Minister John Key was a figure who provoked great ire and anguish amongst the far left (and with Dotcom at a personal level), due to his historic popularity and the dramatic rise of inequality that marked his government. Opposing Key and New Zealand's role in the Five Eyes would only be possible electorally from the left and with an emphasis on the youth vote which had been at historically low levels in preceding elections. To this end, Dotcom entered into a list-sharing agreement with the Mana Party, whose leader Hone Harawira was seen as a shoo-in for the Te Tai Tokerau electorate which would allow IP MPs to coat-tail into Parliament: the IP were unlikely to meet New Zealand's 5\% party vote threshold. The Mana Party's base were the rural indigenous poor of Harawira's electorate, service industry workers, campus socialists, veteran leftists and the remnants of Occupy. While Mana's membership by and large supported the agreement, Mana lost one its most high-profile members in former Green Party MP Sue Bradford who was "disturbed by the idea of going into an alliance with a neoliberal millionaire" (Bennett 2014c). While these fissures were undeniable, the strength of the personalities of Harawira the populist and Dotcom the lulzy man-child produced a unique political spectacle which generated substantial media attention.

Where the IP serves as a useful example of affective media politics was in its confluence of techno-solutionism and left-wing politics. One of Dotcom's most surprising political moves was the selection of Laila Harré as the leader of his party. A former cabinet minister, trade-union activist and self-described "strong social democrat", she told this author that it was essential for the Left to challenge "our assumptions about how people form their political views" (Harré 2014). Among Harré's constituency of digital natives there is a "complete lack of connection to these previous ways [ie left/right binary] of dividing people up" (Ibid.). She believed that the Internet as an organising principle could harness the anti-elitism and anti-corporatism that would link a new youth movement and the working class "base constituency of social-democracy" (Ibid.). Ideological apprehension on the New Zealand Left was largely eclipsed by the excitement around new organisational forms, the potential for the affective energies of youth voters and Dotcom's sizeable investment in the Left. 


\section{Theorising Affective Media and the Political}

This article will argue that the political potential of the Internet, new mobile technologies and interactive media hinge on the question of affect. While the signifier 'social media' obscures the intersection of technology and capital, the term affective media captures specifically the ontological and political-economic logics at work. Affective media are not simply those that circulate the affects of online culture and the intimate details of users, they are a space of the production, performance and quantification of affect. There is a convergence of libidinal and political economies as our lives become enmeshed in the "pleasures of communication" (Terranova 2004, 91) and ceaseless circuits of capital. The promise of user empowerment and new social worlds is what drives the affective labour of posting, sharing and consuming the lives of others as well as our own. Dean writes that under "communicative capitalism" our affective media exchanges are filled with democratic aspirations of "access, inclusion, discussion and participation" $(2009,4)$. With the rise of new media and tech companies as centres of economic and political power, discourses of affective media have become the hegemonic ideal of capitalism, labour and play.

The theoretical foundations of this concept of affective media rest upon Lacanian Marxism (Žižek 1997, 2006, 2008, and Dean 2009, 2010, 2016) and discourse theory (Laclau 2005) which will be expounded shortly. It is first necessary to delineate the Deleuzian formulation of affect theory which predominates in scholarly accounts of new media and enjoys a popular saliency in cyber-utopian discourse. While both approaches ascribe "affect [as] inherently political" (Papacharissi 2015, 19), they differ on the question of political ontology. The difference is between a political subject who is marked by trauma, antagonism and the drive for enjoyment, versus a teleology which sees affect as a prelude to a potential radical democratic becoming. It is necessary to frame these two approaches as affect and new media theorists have posited its explanatory power in events such as Occupy and the Arab Spring. Brian Brown has written that "without the biopolitical influence of the subjective orientation of unwaged digital labourers, social movements such as Occupy Wall Street...would never have come to pass" $(2014,696)$. However, with the rise of Donald Trump and the alt-right's claim to the affective subcultures of the Internet, it is essential to theorise the libidinal and the inter-subjective dynamics of enjoyment as constitutive of the political.

Theories of affective labour, influenced by autonomist Marxism and the affect theory of Deleuze and Guattari, have been crucial to conceptualising the relationship between labour, technology, production and political potential. Hardt and Negri describe contemporary capitalism as driven by "networks based on communication, collaboration and affective relationships" $(2004,66)$. To be affected is concomitant with the ability to affect. Affect is connective and social, passing between subjects and "shap[ing] the surfaces of bodies and worlds" (Ahmed 2004, 121). Even as our social media use is captured as a new intensive form of surveillance and exploitation, under capitalism there is a supposed built-in contradiction to affective media. This alienated labour relies upon a sense of "participat[ing] in something that is bigger than one's self" (Cote and Pybus 2007, 96). This might be contained to forms of online play, self-affirming clicktivism or one's self-branding performances, but it presupposes an encounter with an other. In this way affective media labour is held to create an unintentional being-in-common outside of the factory, with capital increasingly "contradict[ing] the productivity of biopolitical labour and obstruct[ing] the creation of value" (Hardt and Negri 2009, 144). In Hardt and Negri's formulation there is teleology which understands the concurrent developments and contradictions of 
social, productive and technological relations as auguring their indeterminate revolutionary subject, the multitude.

Affect theory and cyber-utopian discourses share a teleology of networked humanity best captured in the political metaphor of the "rhizome" (Deleuze and Guattari 1987, 7). Politics is seen as a series of micro-struggles dispersed through various sites of the social, with flows of intense and contagious affects bringing political subjects into being. Papacharissi speaks of social media's circulation of affect as "activat[ing] latent ties that may be crucial to the mobilization of networked publics" $(2015,20)$. These affective energies coalesce into "interconnected, collaborative and cooperative...heterarchical fluid and dynamic" leaderless movements in the model of Occupy (B. Brown 2014, 696). Concurrent with this vision of social transformation is a depoliticisation of the Internet and associated technologies. Benkler describes new civic-minded modes of peer-production and produsage held as "radically decentralized, collaborative and non-proprietary" (2006, $60)$. The connective tissue between Deleuzian politics and new media optimism is in this principle of immanent human creativity, realised and accelerated through online connectivity.

This vision of politics was nicely encapsulated at the launch of the IP by Dotcom, who called the Internet "the most important innovation to mankind" as it "accelerates our evolution by allowing products to be developed...by people who share information online" (Internet Party 2014f). There is an important slippage here as connectivity becomes production and the Internet is imagined as the social space proper. Andrew Culp writes that in the convergence of Deleuze and cyber utopianism we see the conflation of connection and production obscuring the "technoaffirmationist desire to annex everything" $(2016,64)$. Harré articulates these same ideals in her first speech as leader. For those aspiring to effect political transformation "the new arena is the rapidly changing internet" (Internet Party $2014 d$ ). Harré is self-conscious of her own lack of programming skills or cyber bona fides and instead offers herself up as a 'newb' in awe of the digital natives and their creativity: "You will teach me more about the potential of the internet age in all of its complexity" (Ibid.).

What the celebration of affect and connectivity belies is the political and contingent nature of affective media technologies and the role of antagonism in political identity. The predominant theorisation of affect and the rhizome offers no theory of political rupture outside "people's natural and healthy propensity to revolt" (Laclau 2005, 243). The Lacanian psychoanalytic insights of Dean, Žižek and Laclau foreground the relational, libidinal and inner-psychic elements of affect and affective media production. The distinction is between a phenomenological understanding of affective connectivity - seen as politically productive in its own right - or antagonism as ontologically necessary for political identity. The political subject of affective media is not brought into being by the spontaneous accumulation of affects, but by the libidinal drive for enjoyment. At the centre of this political ontology is the Lacanian subject of enjoyment shaped by trauma and antagonism. Laclau's discourse theory (2005) positions antagonism as the ontological precondition for rupture and social transformation. This is analogous to the loss of the primordial mother and Lacanian symbolic castration which "allows the subject to enter the symbolic order" (Žižek 1997, 17). Political identity is shaped by the drive to recapture this lost enjoyment and the spectre of the 'other' who has taken it.

For Laclau, antagonism and affect are coupled in the process of political articulation. Any properly political movement must divide the social space between 
the political community and an enemy. In his theory of populism Laclau states that this community comes into being through an "affective investment in a partial object" $(2005,116)$. A signifier/name becomes overdetermined, eliciting and unifying the emotional energies of followers. This is the logic of Lacan's objet petit a, where a signifier stands in for the primordial mother/child relationship or "the absent fullness of society" (Ibid., 226). Thus in the signifiers 'Occupy', 'Anonymous' or 'Internet Party' there is an affective political power which imagines a community and its enemy; whether 'Big Brother' or the '1\%'. The IP works on the power of the signifier - 'The Internet' - as a god term eliciting other floating signifiers of cyber-utopianism: 'Web 2.0 democracy', 'citizen-consumer/prosumer', 'DIY' 'freedom/liberty', 'transcendence' (Dahlberg 2010, 337). These affective investments are catachrestic: what is desired is never quite as it should be, and this displacement propels one into further affective drives. As an anti-essentialist, Laclau would see the battle to define 'The Internet' as a wholly reconciled social space as representative of the contingency and incompleteness of the social as such.

Žižek and Laclau fundamentally differ on the question of affect and enjoyment as a political logic. Laclau ascribes affective investment as unfixed, standing in for the heterogeneity of the social space. For Žižek the problem here is that affect and enjoyment calcify into a fetishistic politics. Where Deleuzian affect theory presupposes the productivity of human connectivity, the Lacanian subject of psychoanalysis is insular and wracked by the presence of the other. Enjoyment is dependent upon the other and is never our own but is "concentrated in the other who stole it from us" (Žižek 1997, 43). The parasitic, overdetermined enemy cannot be eliminated as they are essential for enjoyment and protect the populist from assuming "the full ontological weight of [their] world experience" (Ibid., 60). Žižek's critique of Laclau's concept of the political and populism (2006 and 2008) centres on this question of a fetishistic investment in the enemy who is "reified [into] a positive ontological entity" (Žižek 2008, 278) necessary for the community's enjoyment.

This is key to understanding how trolling functions as a defining subcultural practice of affective media. Brutally mocking an other is enjoyed, yet this other is an object of obsession and outrage. This is the obscene enjoyment of jouissance which is pursued for its own sake and generates both a fear of the enemy's omnipotence and an enjoyment in their dehumanisation. Jouissance produces a self-fecund conspiratorial drive to understand the depths of the enemy's depravity and further enmesh one in this fetishised circuit of enjoyment. This is precisely how cyberlibertarians construct their enemies in the national security state as a system of omnipotent jouissance, from lecherous TSA agents to the spectre of NSA agents looking at your porn consumption, rather than a bureaucracy which embodies the same techno-rationalism that cyber-utopians exalt.

Affective media should not be thought of as political in and of itself, but rather as simultaneously displacing and accelerating the logics of enjoyment and antagonism which are the precondition for political identity. The reduction of connectivity and creativity as the political belies the way in which affect and libidinal drives can become trapped in circuits of capital or explode as populist jouissance. What the following analysis of the IP will advance is a dialectic of affective media's political potential between a left techno-democracy fetishism and the articulation of an antagonistic cyber-libertarian political project. The deployment of affect as a political strategy oscillates between enlisting partisans through a playful irreverence, the circular enjoyment of seemingly democratic processes, or a politics of pure jouissance. This is not meant as a totalising theory of affective media politics; 
however, it is clear that the reliance on connectivity does not overcome the deadlocks of $20^{\text {th }}$ century emancipatory leftist thought. Dean's work on the communist party as an "affective infrastructure" $(2016,291)$ might be better suited to formulating affect within a radical left politics but is beyond the scope of this article.

\section{Trolling and the LULZ}

The IP's strategy to mobilise the youth and digital natives was to channel affective online cultures in offering a new irreverent politics fusing technological innovation and 'the LULZ'. This is implicit in the signifier 'Internet', which in addition to the righteous affirmation of cyber-utopianism signals the affective pleasures of identification. The IP campaign was staked on melding its serious message with the spirit of lulzy irreverence and nerd culture which defines the 'weird Internet' of Twitter, Reddit and 4chan. Whether through the use of cats in promotional material, because nothing is more 'Internet' than cats, the national concert series emceed by Dotcom or the party's online videos, the IP's 'serious' message was delivered through affect. The party's televised opening campaign statement features a Jetsons-style retro-futurism in which the IP usher in prosperity, environmental stability, cyber-protection, "awesomely radical hoverboards and talking cats, because futuristic reasons!" (Internet Mana Party 2014). The comedic mechanism of the "because reasons" meme is exemplary of the circularity of affect as a political logic. The popular blogwriting style of turning "because" into a noun is supposed to function as an "explanation that maximizes efficiency and irony in equal measure" (Garber 2013). The non sequitur "because futuristic reasons" is a meme folded into itself that is symbolically efficient on the basis of an affective investment in 'The Internet'. Selfparody and sincerity sit side-by-side. The key insight is that there is no gap between the affective pleasures of political identity and programmatic ideological content. Belief in techno-solutionism and cyber-utopianism provide a form of enjoyment and the affective energies for political/antagonistic articulation.

In identifying the affective community of the Internet it is necessary to delineate an other as an object of ridicule and enjoyment. The IP's political enemies are, predictably, arms of the security state, John Key, the American government and what Dotcom calls the "copyright cartel" who try "take control and monopolize all of human thought" (Keiser 2016). While there are burning political discussions to be had about state surveillance, New Zealand's geo-political alliances, intellectual property and what the digital commons might look like, these enemies, in IP discourse, serve as objects of jouissance. America is a potent signifier of indeterminate evils in IP discourse, eliciting the battle cry of "let's take this country back from the Americans!" (Ryan 2014). The populist binary of fear and enjoyment is rendered perfectly in a series of IP videos entitled "Bedtime Stories With the GCSB" (Internet Party, 2014g). The videos are intended as a satire of Masterpiece Theatre and feature readings of Greenwald's severe prose on state surveillance: "[Five Eyes] is devoted to one overarching mission to prevent the slightest piece of electronic communication from evading its systemic grasp". The video contains a subliminal jump cut of the "Great Seal of the United States' before concluding with a sign-off: "sleep tight New Zealand, be safe and remember wherever and whoever you are the GCSB is there too". The dissonance between the paternalism of a public broadcaster and government that watches you when you sleep is meant to be humorous, but it is precisely what is elicited in their concept of surveillance as bureaucratic jouissance. America's omnipotence or manipulation is light-heartedly compared to conspiracies of the Illuminati and the new-world-order, yet this is how the IP conceive their enemy. 
The affective media practice of trolling exemplifies the circular logic of jouissance; obsessing over and mocking the enemy becomes an end in and of itself. Phillips' study of 'troll' subcultures emphasises a Bergsonian "affective gap" $(2015,35)$ between offensive trolling content and its dispassionate delivery. It is this dissonance which sustains online subcultures as a place of play. However in the IP's Illuminati conception of the enemy there is no ironic distance, in spite of the lulz enjoyed in this caricature. Some theorists have turned to the hacker group Anonymous as an example of how the affective drive for lulz can be sublimated into "the pursuit of a rational political goal" (Stoehrel and Lindgren 2014, 257). Yet whatever progressive outcomes may be achieved by the lulz of obscene enjoyment, jouissance has its own logic. In Gabriella Coleman's 2014 book on Anonymous, the notorious white supremacist hacker 'weev' is profiled as an archetypal troll concerned only for the lulz, which Coleman sees ultimately as a "principled weapon" of resistance (50). For Coleman, the world of racism, misogyny and snuff that hackers inhabit is the shocking carnivalesque which gives trolling its subversive power. The obvious mistake here is failing to take jouissance and weev at face value. The so called altright have perfected the use of affective media as a political tactic in mobilising behind Donald Trump as an avatar of pure vulgar jouissance. The alt-right even mirror the affect determinism of cyber-utopianism with their concept of 'meme magic'. The logic of trolling exemplifies the other's role in enjoyment as both an object of derision and obsession. Enemies are a source of enjoyment to be 'triggered' with heinous provocations, while still plaguing the alt-right with thoughts of political correctness on campus, or pure racist nightmares of miscegenation and sexual enjoyment.

Kim Dotcom was foregrounded in the IP campaign as an avatar of lulz trolling the Prime Minister. A key part of his biography on the campaign was his claim to have hacked NASA at the age of 19 to see if aliens existed (Ryan 2014); in other words, 'he did it for the lulz'. Additionally his garish lifestyle, his world \#1 ranking in Call of Duty and his status as a self-produced electronic dance music DJ made him a star attraction on the IP Road Trip. Dotcom's musical catalogue typifies what politics the lulz undergirds ${ }^{2}$. Dotcom's lulzy irreverence has also seen him flirt with Nazi iconography, having been photographed wearing an SS helmet and owning an autographed first-edition copy of Mein Kampf. Dotcom stated that the photo was a joke, that the book was a lucrative investment and that as a Call of Duty player he clearly has an interest in history (Bennett 2014a). While Dotcom is not weev, the fascination with an ahistorical Nazism is key to the moral absolutism of the cyberlibertarian struggle with state power. Leaving no doubt about the narcissism and hysteria common to this politics, Dotcom has subsequently claimed that his treatment at the hands of America, colluding with Jewish Hollywood moguls, was akin to Nazism (Dotcom 2015).

The centrality of Dotcom to the campaign is owed to his relationship with John Key as the Prime Minister and minister for the GCSB. The two exchanged jabs during Dotcom's testimony to a parliamentary select committee and Dotcom was instrumental in transforming the PM into a populist enemy and target of derision. While in historical terms the neo-liberal PM has simply maintained the status quo of previous governments' security arrangements with Five Eyes, he was routinely panned as a puppet and sycophantic bootlicker of the American empire, particularly

${ }^{2}$ The song "Live my Life" (Dotcom, 2012) follows a nerd through gratuitous soft porn fantasies of hyper-masculinity, while the $\$ 24$ million video "Good Life" (Dotcom, 2016), described by Dotcom as his life's work, is a display of pure hedonistic opulence. 
in the bizarre 'Project Manifesto' party video (Internet Party 2014c). This jouissance burst into the national discourse with the release of the infamous "Fuck John Key!" video. Initially published on the party's YouTube page, the video captured the lulz and the role of Dotcom as troll. Dotcom addressed a frenzied crowd in Christchurch, promising to lead a "revolution", and "extradite" John Key (Internet Mana Party 2014b). The concert-goers then proceeded to chant "Fuck John Key" while Dotcom held a cardboard cut-out of Key. What is striking about this incident is the emptiness of the term 'revolution'. Only a deeply ahistorical reading of Key allows one to entertain the notion that the IP's cyberlibertarianism represents anything close to revolution. While Dotcom positions himself as master of the lulz for the universal principles of 'the Internet', we simply have jouissance deployed at the figure Dotcom holds responsible for destroying his business and seizing his property (Bennett 2014b).

\section{Techno-Democracy Fetish}

Theorising affective media ontology, we encounter a dialectic between technohumanist teleologies of democracy and the reality of the political, lulz and populism. To understand how depoliticisation and ideological misrecognition are built into affective media practices it is necessary to consider Dean's notion of "Communicative Capitalism" as a convergence point of libidinal and political economies. Affective media draws on the anxieties and pleasures of communication and commensurate incessant loops of surveillance capital. In the pursuit of rationalist Habermasian communicative action and consensus, we are forever caught in the Lacanian intersubjective dynamics of enjoyment: 'What did the other mean? What did the other see in me? Are they trolling me?'. The affective investment in virtual democracy produces a hyper-activity in pursuit of pure communication, consensus and taxonomical politics. In this way, virtual democracy is depoliticisation "extend[ing] affective networks without encouraging - and indeed, by displacing - their consolidation into organized political networks" (Dean 2010a, 42). Techno-mediated communication becomes a fetish which "covers over a fundamental lack or absence in the social order...[and] the 'fix' lets us think that all we need is to extend a particular technology and we will have a democratic or reconciled social order" (Dean 2009,38 ). At the height of this techno-fetishism, subjects are interpassive: we behave as if we are active but the "technological fetish 'is political' for us, enabling us to go about the rest of our lives relieved of the guilt that we might not be doing our part" (Ibid., 37).

The IP offered techno-solutions to questions of democracy, governance and party structure which appealed to an Occupy-inspired left. While 'democracy' surfaces frequently in IP discourse, it fits within the rhetoric of the sharing economy, NGOs and social enterprises where 'democracy' is akin to good corporate governance. At the party's launch, Dotcom announced that the IP would embody "truly democratic processes that no other party has... [a] crowd sourc[ing] policy" allowing members to collaborate (Internet Party 2014e). The IP's notion of radical democratic party processes also included the gamification of candidate selection, as members performed in an American Idol-style spectacle, with winning candidates standing for office. The IP's policy on "Responsive Government" promised a one-stop "democracy portal" that would allow citizens to vote online and collect signatures for binding citizen-initiated referenda (2014a). It promised to modernise and save money on government services through the use of open-source software, and tap in to problemsolving start-up culture through public hackathons and app challenges (Ibid.). In spite 
of Occupy rhetoric, the IP's tech-disruption of politics equates democratic citizenship with the autonomous neo-liberal digital subject. The IP's governance policy aligns with the neo-liberal rubric of "right-sizing government", reducing "welfare dependence" and providing better service to business (Ibid., 5-10).

The techno-fetishist rhetoric of democracy reached its apogee in partnering with Loomio to launch the IP's policy incubator. Loomio is a conferencing app developed by members of Occupy Wellington, and modelled on the Occupy general assembly. The app allows members to advance proposals, block or approve them, abstain or counter-propose. Prominent cyber-utopian theorist Douglas Rushkoff served as a mentor and booster of the Loomio project, declaring it the killer-app for democracy (Rushkoff 2014). Loomio creator Ben Knight explained the power of this techno-fix to democracy at a TEDx talk through the testimony of a Brazilian protester who wrote to him:

Your software seems to be exactly what we need right now...to give us the space we need to transform our dreams into concrete action. To help us re-learn how democracy is made: through engaged discussion and informed participation (Knight, 2013).

The fetish of democracy transposes the hard work of the political ideology and the division of the social onto software that enacts radical democracy without threatening the autonomy of neo-liberal digital subjects in the quest for pure communication and consensus. The techno-democracy fetish creates an endless discussion, reinforcing the virtues of communicative capitalism while infiltrating the everyday and colonising our dreams of democracy.

The IP's policy incubator was a demonstration of how the horizontalist notion of communication and "structurelessness" becomes a "way of masking power" (Freeman 1973, 6). The sole policy achievement of the incubator was initiating a conversation on medical marijuana and decriminalisation, later turned into policy. As a party whose raison d'etre was youth mobilisation and opposing state power, this is hardly controversial policy. What this consensus-forming exercise produces is the affective communicative energy sustaining the myth of the 'crowd-sourced' policy and the fantasy of techno-democracy. In a candid interview with the present author, Vikram Kumar, the former CEO of Dotcom's Mega and the CEO of the IP, was asked whether the incubator delivered tangible outcomes, to which he gave a decidedly realist answer: "I think people have this concept that somehow you crowd-source policies, or you put up a topic and magically people will come up with the best answers; it doesn't work that way" (Kumar 2014).

Kumar continued that in practical terms Loomio puts the party in conversation with its members and gauges their various interests. The policy incubator is simply an online version of the focus group approach that defines modern professional post-politics, turning ideological positions into data points. It is telling that Kumar was named CEO of the party while party president. A tech-elitism was enshrined in the party constitution where Dotcom was officially titled 'party visionary', meaning that he could not be removed from the executive position by party members ( $R$. Brown 2014). The party's assets were placed in a shell company, administered by the party secretary as an employee of the company not answerable to party members (Ibid.). It is apparent that the IP's use of Loomio is about displacing politics, using the democracy fetish to placate a leftist sensibility as part of a well-resourced, 
professional political attempt to steer young people towards the class project of cyberlibertarianism.

\section{Cyberlibertarianism}

Behind the indeterminacy of affective media signifiers and the techno-democracy fetish lies the class project of cyberlibertarianism. The rhetoric of decentralisation masks new forms of control that allow tech-capital to extract affective labour. While this might seem an intolerable hypocrisy, the exaltation of digital liberty lays the groundwork for neo-liberal individualism and autonomy. Freedom online becomes the "freedom to consume through financial payment ....and freely choosing to give away your labour to corporations in exchange for non-monetary opportunities and benefits" (Dahlberg 2010, 340). Cyberlibertarianism deploys the metaphor of a global frontier, with all the rugged individualism this entails. However, the libertarian critique of corporate inauthenticity offers the Left the promise of "replacing corporate capitalism and big government with a high-tech gift economy" (Barbrook and Cameron 1996, 6) through the free flow of information and superior modes of exchange such as Bitcoin. The IP championed this vision of freedom explicitly in its governance and economic policy statements, and Dotcom himself characterised his company Mega as part of the rhizomatic infrastructure of Internet freedom. In cyberlibertarian discourse we have the melding of commercial imperatives and idealism which channels "leftist political energies into the service of the political far right" (Golumbia 2013, 3).

Cyberlibertarianism is not merely leftist confusion and manipulation by tech capital: in true populist form there is a moral piety which masks a dystopian elitism and libidinal investment in techno-mastery. Golumbia identifies in cyberlibertarianism a Hobbesian view of individual power over and above civil society as the basis for sovereignty $(2009,192-196)$. In the political interventions of tech-capital, hackers and anonymity-activists there is a belief that "unsolved problems simply indicate that nobody as smart as they are has come along to solve those problems; that domainspecific knowledge is a kind of 'elitism' meant to keep out true experts like them" (Golumbia 2015, 125). We can see this in the 'techno-solutionism' which informs the IP's policies of ICT-driven education, promotion of digital currencies, the softwarecentric view of the economy and the aspiration to become "the world's start-up incubator" (Internet Party, 2014b). With this naïve faith in tech comes a belief in "spontaneous order" (Golumbia 2013,6) brought about through the hacker-ethos of disruption. The hacker may bypass "anything that gets in the way of the individual" (Ibid., 15) whether barriers to information or accountable political processes, as they attempt to liberate institutional knowledge for the netizenry.

One of the great achievements of cyberlibertarianism is the ubiquity of the hacking metaphor: from life-hacks to food-hacks to politics. There is an individualism that is hostile to the traditional mass politics of the Left and holds an ambiguous relationship to tech capital, as besting the tech establishment allows hackers to "promote themselves as the most effective and most highly-skilled candidates for employment" (Golumbia 2013, 15). Individualism aside, there is a libidinal logic of power "inspir[ing] dreams of individual domination and mastery, of a self so big that no other selves would be necessary" (2009, 184). Beyond the nominally left tech-fetishism of virtual democracy, cyberlibertarianism offers individual transcendence of the social with computer mastery proving "sexually satisfying to the adolescent who already feels estranged from human social relations" (Ibid., 187). The hacker is trapped within the fetishistic logic of jouissance, deriving pleasure and superiority from computer 
mastery while continually reencountering the failure of this "relation between the self and ordinary people" (206).

As a populist politics of jouissance, cyberlibertarianism vacillates between the moral piety of the digital community and a dystopian distrust of the masses. In his examination of the politics of Anonymous, Goode identifies the split between utopia/dystopia and nihilism/idealism (2015). Goode describes a cultish language of religious awakening crossed with The Matrix that would not be out of place on the Glenn Beck show:

"All your life you have known that something is not right with this world. You can FEEL it in your heart. We all can. Anonymous is here to realign the people with the truth." (Goode 2015, 81.)

Goode writes that "these pious tones could be dismissed as the humorous echoes of films such as V for Vendetta and The Matrix" (Ibid.). Whatever lulz are gained from the appropriation of nerd fan cultures and a comic book morality, there is no ironic distance between jouissance and super-hero fantasies. Dotcom was routinely introduced at IP events as "New Zealand's newest Superhero" (Ryan 2014). Indeed, Edward Snowden has stated that his political awakening was born of video games, where "an ordinary person finds himself faced with grave injustice from powerful forces and has the choice to flee or fight for his beliefs" (Kakutani 2014). Cyberlibertarians may well consider their struggle as the fight against "abject slavery", "the nightmarish vision of 1984" and "the new world order" (Anonymous, quoted in Goode 2015, 82) but this struggle is too important to be trusted to the masses. As an individualistic politics of jouissance, there is a non-dialectical view of power in moral absolutist terms, oscillating between hero-worship and hysterical disempowering dystopianism. The model of hacker politics here is not unlike the culture jammer that dismisses the public as "totally programmed by the culture of the spectacle" (Haiven 2007, 87), i.e. trapped in the Matrix and so therefore an enemy. The hacker or culture jammer is free to act out their personal emancipation with no need to "be critically and reflexively scrutinized for their effectiveness or participation in broader forms of oppression" (Ibid., 98). The hacker doesn't need politics or ideology, but simply submits to the logic of information, taking no responsibility for anything beyond revealing a truth which the public may or may not choose to accept.

\section{Moment of Truth}

The IP's "Moment of Truth" was the culmination of a highly-managed professional political campaign, crystallising the politics of cyberlibertarianism. The event was promoted two months in advance and promised a "political bombshell" (Manning 2014) five days before the election. Beyond the notion of disruption inherent in this political unmasking or 'September Surprise', this was a clear end-run around conventional politics. The event sought to bypass professional journalism while simultaneously managing the spectacle in line with the superficial media values that the party is supposedly critical of. Delaying the release of the information also allowed the IP to assemble a star-studded billing of cyberlibertarian heroes. Glenn Greenwald was announced, with the promise of revealing damning evidence of the Key government's complicity in mass domestic surveillance. Greenwald chose not to work with New Zealand journalists prior to the event, in spite of the experience of exemplary journalists like Nicky Hager, who first exposed Five Eyes to the world in 1995, or Andrea Vance, who broke the story of the GCSB's illegal spying and was 
herself subjected to government surveillance. Whatever the merits of Greenwald's reporting, there is a hacker's sensibility that the local context for journalism and politics are inconsequential in the face of Snowden's powerful, disruptive information. It is this elitism and dismissal of national specificity that allowed Key to deflect Greenwald's reporting, appealing to the public that Greenwald was simply Dotcom's "little henchman" (Trevett 2014).

The principal effect of the MOT event was to position Dotcom, the IP and the New Zealand elections as part of the universal struggle for Internet freedom. Harré introduced the meeting as "a symbol of democracy for the whole world...courtesy of the internet itself" (Moment of Truth 2014). Fittingly, the giants of cyberlibertarianism Julien Assange and Edward Snowden joined by video-link. Each offered their sombre assessment of current mass government surveillance and entreated the New Zealand public to end mass surveillance. Greenwald used NSA documents to show that Key's government intended to tap the Southern Cross cable, and Snowden claimed first-hand knowledge of New Zealand's participation in the NSA XKeyscore program, as well as the existence of two NSA offices inside New Zealand. While these are very newsworthy claims, they were undone by a cyberlibertarian condescension. Greenwald's performance mirrored the IP's campaign by turning Key into a figure of contempt. He gleefully mocked Key, to Dotcom's unrestrained laughter and the delight of his audience, while emphasising his own altruistic motives. He referred to Key's media attacks as "the most adolescent epithets imaginable" (lbid.):

I guess in some warped way New Zealanders should feel blessed to be led by a person who has completely unburdened himself...I mean he has no dignity or statesmanlike behaviour...I never thought I would actually hear myself saying..."I'm not going to lower myself to the prime minister's level"[Laughter]. (Ibid.)

Greenwald attacks the notion that he is endorsing the IP as a conspiracy "so frivolous that nobody could say it with a straight face", yet at the same time states that he is "thrilled" that Dotcom is funding the party and is "really proud" to participate in MOT as a "pure affirmation" of his role as a journalist (Ibid.). This apparent contradiction can only be reconciled by a cyberlibertarian notion of information as over-and-above politics. As the gatekeeper of Snowden's NSA documents, Greenwald's intervention is virtuous by default and requires no consideration of national specificity as Greenwald states in defence of his motives: "I have spent very little time studying the domestic political disputes that take place in New Zealand" (Ibid.).

Greenwald's most remarkable rhetorical flourish, in defence of his journalistic ethics, neatly evinces the utopian/dystopian binary and cyberlibertarian piety. The derision of Key reaches a crescendo in Greenwald's characterisation of the pathological enemy:

People who make accusations about other people's hidden corrupt motives are actually saying very little about the people they're accusing but saying a great deal about themselves. Because what those people are saying, the people who spew those kind of accusations, is, "I cannot believe that anybody would do anything out of a sense of duty or principle. They must be doing it for some corrupt reason." And the reason they think that is because they themselves never do anything out of 
conviction or principle. And so they believe that everybody else is plagued by the same pathology of soullessness that plagues them (Ibid.).

The populist formulation is clear; the enemy and mass surveillance are understood in a Manichean language we might associate with the religious right. The enemy is "plagued" by a fundamental corruption and "pathology of soullessness" which can be called jouissance. And just as this jouissance marks the enemy as irredeemable, Greenwald and Dotcom can imagine themselves as real moral agents acting out of "a sense of duty or principle"3.

MOT proved a debacle not simply because of a cyberlibertarian jouissance and derision, but also Dotcom's failure to produce his smoking gun. His revelation was to be an email from a Hollywood executive discussing with John Key a plan to entrap Dotcom; however, the email could not be independently verified. Without his big reveal, Dotcom was left on stage in his familiar role as lulzy cheerleader laughing at Greenwald's jokes and 'whoo'-ing into his live microphone. At the conclusion of Snowden's and Assange's talks he gave his only substantive contribution of the evening:

There are two ways to fight mass surveillance. Number one is politically....Number two, with technology. 'Encryption' is the key word ...what you have witnessed tonight is quite extraordinary because both Julian and Edward have been connected to us using our new Mega communication suite, which is a fully encrypted videoconferencing solution. So I am really passionate about keeping everybody's status safe. Not only can you transfer files completely privately and securely through Mega, you can also communicate with a Skype-like client on steroids completely safe and web based (Ibid.).

Presented as a public intervention in New Zealand politics, the big reveal at MOT was Dotcom's cyberlibertarian conflation of freedom and human rights with private profit. Whatever insights the public may have gained about the question of government surveillance were eclipsed by Dotcom's product launch and selfcongratulatory techno-solutionism, endorsed by Assange and Snowden, who appeared on-screen with the Mega watermark. Self-interest aside, the political solution of encryption is a form of tech-fetishism that both fails on its own terms and perpetuates the cyber-libertarian view of state power ${ }^{4}$.

\section{Conclusion}

The formation of the Internet Party was premised upon key notions of affective media politics. Their campaign was to unlock the irrepressible sociality of Web 2.0 with new political and economic potential from hackathons, crowd-sourced policies and a

\footnotetext{
${ }^{3}$ This pronouncement is truly remarkable when we consider that Greenwald's exclusive access to the Snowden files has been leveraged to secure a $\$ 250$ million investment from eBay founder and cyberlibertarian guru Pierre Omidyar to create First Look Media and The Intercept (Ames, 2013a). The cyberlibertarian conflation of private interests with virtue is transparent in the privatisation of the Snowden files by Greenwald, in conjunction with a Silicon Valley oligarch whose company boasts of routinely sharing its customers' information with law enforcement without a subpoena or warrant (Ames, 2013b).

4 Yasha Levine's journalism on the Tor Project is exemplary here as Tor both fails the test of encryption and disavows its government funding and role as a soft power mechanism in US foreign policy (2015a and 2015b).
} 
youthful tech-connected constituency. The battle for a libertarian Internet was pitched as a universal struggle that rhizomatically realized an autonomous movement overcoming the challenges of traditional mass politics and ideology. The IP positioned itself within the left of New Zealand politics and appealed to the democratic proceduralism of Occupy, yet there were clear signs of a techno-elitism behind the rhetoric of the rhizome. What affective media has wrought in the IP is a populist politics of jouissance which conceals the class project of cyberlibertarianism.

What was new and expressly political in IP discourse was the centrality of affect and lulz in its political strategy. Affective media enables a collective experience of enjoyment which is critical to what Laclau would term an antagonistic discursive articulation. The IP was able to create a political identity of irreverent enjoyment with no gap between the 'serious' message of cyber-utopianism and a lulzy internetsubcultural identity. While affect can be political, the potential for a populist fetishism is clear. Correlative to the IP's political identity is a rapacious enemy of jouissance, described in conspiratorial Illuminati-esque terms of omnipotence and pathological soullessness, whose own perverted enjoyment threatens the group. It is this populist fetishism which explains the IP's ahistorical and overwrought view of state surveillance. It also allows Dotcom the ability to troll John Key as a figure of contempt and claim his own libertarian self-interest as some manner of revolutionary idealism.

While there has been excitement in academic and left-wing circles about the ability of affective media and techno-solutions to enable new democratic processes, the IP's version of the 'new' masks the power of the tech-oligarchy. The party's corporate governance, Dotcom's 'visionary' status, and undemocratic internal processes clearly indicate that Dotcom's self-interest overrides the party membership. The use of the Occupy-inspired Loomio's policy incubator corresponds precisely to Dean's notion of techno-fetishism whereby hyper-activity, proceduralism and the quest for an impossible pure discourse replaces direct political action. While appealing to a leftsensibility of new politics the policy incubator was simply a means to focus-group its membership in a manner typical of conventional professional politics.

Where affective political energies were realised for ideologically substantive politics, this was in the service of cyberlibertarianism. Dotcom is able to conflate the struggle for digital liberty with the rights of tech-capital and his business to be free of government interference. Despite the semblance of left-wing notions like democracy, sharing and the commons, cyberlibertarianism is a politics of radical capitalist individualism with an extreme right-wing view of government and the masses. The model of political action is the hacker as pious superhero, an autonomous individual whose superiority licenses all manner of disruption and political interventions. There is a libidinal investment in technical mastery as overcoming the irrationality of the social world and the inevitable dystopian anger when the public fail to yield to individual greatness.

The Moment of Truth was a precisely cyberlibertarian political intervention combining journalistic insights with a management of political spectacle aimed at vaulting Dotcom to the pantheon of cyberlibertarian heroes while using Snowden and Assange to 'launch' his new product. This end run around journalism and the public failed spectacularly, as Dotcom was unable to produce his smoking gun. Greenwald and Dotcom's derision of the unprecedentedly popular prime minister may have produced lulz for the IP's constituency, but it hardened the general public against the party. Support for the Internet Mana list collapsed from a high of $4 \%$, with five potential MPs, to a polling day low of $1.26 \%$, leaving them outside of parliament (TVNZ 2014). While this political intervention may not have dented Dotcom's 
credibility in cyberlibertarian circles, the lessons for left-wing enthusiasts of affective media politics are clear. The Mana Party of left-radicals and the indigenous rural poor, who entered parliament through traditional organising, campaigning and leftwing solidarity, were decimated and discredited by this techno-democracy gambit.

\section{References}

Ahmed, Sarah. 2004. Affective Economies. Social Text 22 (2): 117-139.

Ames, Mark. 2013a. Keeping Secrets. Pando. Accessed February 14, 2016. https://pando.com/2013/11/27/keeping-secrets/

Ames, Mark. 2013b. Team Omidyar, World Police. Pando. Accessed February 14, 2016. https://pando.com/2013/12/14/team-omidar-world-police-ebay-puts-user-data-on-asilver-platter-for-law-enforcement/

Barbrook, Richard and Andy Cameron. 1996. The Californian Ideology. Science as Culture 6 (1): 44-72.

Benkler, Yochai. 2006. The Wealth of Networks. New Haven: Yale University Press.

Bennett, Adam. 2014a. Nazi Blindside for Dotcom. New Zealand Herald. Accessed December 11, 2015. http://www.nzherald.co.nz/nz/news/article.cfm?c id=1\&objectid=11227076

Bennett, Adam. 2014b. Dotcom's Party Hits 1000 Mark. New Zealand Herald. Accessed December 14, 2015. http://www.nzherald.co.nz/nz/news/article.cfm?c id=1\&objectid=11227984

Bennett, Adam. 2014c. Bradford Walks Out of Mana AGM. New Zealand Herald. Accessed December 14, 2015. http://www.nzherald.co.nz/rotorua-dailypost/news/article.cfm?c id=1503438\&objectid=11237475

Brown, Brian. 2014. Will Work For Free: The Biopolitics of Unwaged Labour. triple-c: Communications, Capitalism \& Critique 12 (2): 694-712.

Brown, Russel. 2014. The Internet Party Whatever Happens. Public Address. Accessed February 2, 2016. publicaddress.net/system/cafe/hard-news-the-internet-partywhatever-happens/?p=308839\#post308839

Coleman, Gabriella. 2014. Hacker, Hoaxer, Whistleblower, Spy: The Many Faces of Anonymous. London: Verso.

Coté, Mark and Pybus, Jennifer. 2007. Learning to Immaterial Labour 2.0: MySpace and Social Networks. Ephemera. 7 (1): 88-106.

Culp, Andrew. 2016. Dark Deleuze. Minneapolis: University of Minnesota Press.

Dahlberg, Lincoln. 2010. Cyberlibertarianism 2.0: A Discourse Theory/Critical Political Economy Examination. Cultural Politics 6 (3): 331-356.

Dean, Jodi. 2009. Democracy and Other Neoliberal Fantasies. Durham: Duke University Press.

Dean, Jodi. 2010a. Affective Networks. Media Tropes 2 (2): 19-44.

Dean, Jodi. 2010b. Blog Theory. Cambridge: Polity.

Dean, Jodi. 2016. Crowds and Party. London: Verso.

Deleuze, Gilles and Guattari, Felix. 1987. A Thousand Plateaus. Minneapolis: Minnesota University Press.

Dotcom, Kim. 2012. Live My Life. Accessed September 27, 2015. https://www.youtube.com/watch?v=ThwijKKemS4

Dotcom, Kim. 2015. Twitter status update. Accessed January 29, 2016. https://twitter.com/KimDitcom/status/552329967678545920

Dotcom, Kim. 2016. Good Life. Accessed January 29, 2016. https://www.youtube.com/watch?v=oDiili2Gs-0

Freeman, Jo. 1973. The Tyranny of Structurelessness. Berkeley Journal of Sociology 17: 151-165.

Garber, Megan. 2013. English has a new Preposition, Because Internet. The Atlantic. Accessed February 7, 2016. 
https://www.theatlantic.com/technology/archive/2013/11/english-has-a-newpreposition-because-internet/281601/

Golumbia, David. 2009. The Cultural Logic of Computation. Cambridge: Harvard University Press.

Golumbia, David. 2013. Cyberlibertarianism: The Extremist Foundations of 'Digital Freedom'. Uncomputing. Accessed February 2, 2016. www.uncomputing.org/? $\mathrm{p}=276$

Golumbia, David. 2015. Bitcoin as Politics: Distributed Right-Wing Extremism. Moneylab Reader: An Intervention in the Digital Economy. Amsterdam: Institute of Network Cultures.

Goode, Luke. 2015. Anonymous and the Political Ethos of Hacktivism. Popular Communication 13 (1): 74-86.

Haiven, Max. 2007. Privatized Resistance: Adbusters and the Culture of Neoliberalism. The Review of Education, Pedagogy and Cultural Studies 29 (1): 85-110.

Harré, Laila. 2014. The Revolution Will Not Be Televised. Radio One 91fm. Accessed March 2, 2016. https://soundcloud.com/olivier-jutel/laila-Harré-internet-party-nz

Hardt, Michael and Antonio Negri. 2004. Multitude. New York: Penguin Press.

Hardt, Michael and Antonio Negri. 2009. Commonwealth. Cambridge: Harvard University Press.

Internet Mana Party. 2014a. Official Electoral Opening Statement. Accessed January 22, 2016. https://www.youtube.com/watch?v=JpyHdnQt5fw

Internet Mana Party. 2014b. Join The Revolution. Accessed January 29, 2016. https://www.youtube.com/watch?v=O3NpLijPIXk

Internet Party. 2014a. Responsive Government: Full Policy. Accessed February 4, 2016. https://doc.google.com/document/d/1YD9VpZVwPYHgf4yi2z7jRxrx9w5Bfv1VNx869RXcQQ/edit

Internet Party. 2014b. Digital Economy \& Innovation: Full Policy. Accessed February 2, 2016. https://docs.google.com/document/d/1WsUDgnRSjcHOxpQtWOiZnhAdJaHOywOL7X6 1Us84fBY/edit

Internet Party. 2014c. Project: Manifesto. Accessed February 2, 2016. https://www.youtube.com/watch?v=YO07KTU3jEU

Internet Party. 2014d. Introducing: Laila Harré - Leader of the Internet Party. Accessed February 2, 2016. https://www.youtube.com/watch?v=8Hr8D6wlYk8

Internet Party. 2014e. Crowd Sourced Politics. Accessed February 3, 2016. https://www.youtube.com/watch?v=-18TF5Uyog4

Internet Party. 2014f. The Internet is Under Attack. February 3, 2016. https://www.youtube.com/watch?v=X3LdzGsqnV4

Internet Party. 2014g. Bedtime Stories With The GCSB. Accessed January 29, 2016. https://www.youtube.com/watch?v=JMoL9KR-QPE

Kakutani, Michiko. 2014. Snowden's Story Behind the Scenes. New York Times. Accessed February 14, 2016. http://www.nytimes.com/2014/05/13/books/no-place-to-hide-byglenn-greenwald.html? $r=0$

Keiser Report. 2016. Business Death...Allegedly. RT. Accessed March 21, 2017. https://www.youtube.com/watch?v=QFPTwAV4P0A

Knight, Ben. 2013. TEDx Talks: How Technology Can Enable Everyday Democracy. Accessed March 3, 2016. https://www.youtube.com/watch?v=4vCL4I19o9U

Kumar, Vikram. 2014. The Revolution Will Not Be Televised. Radio One 91fm. Accessed March 2, 2016. https://soundcloud.com/olivier-jutel/vikram-kumar-and-rob-stewartinternet-party-nz

Laclau, Ernesto. 2005. On Populist Reason. London: Verso.

Levine, Yasha. 2015a. Internet Privacy Funded by Spooks. Pando. Accessed February 7, 2016. https://pando.com/2015/03/01/internet-privacy-funded-by-spooks-a-brief-historyof-the-bbg/

Levine, Yasha. 2015b. Tor Project. Pando. Accessed February 7, 2016. https://pando.com/2015/12/18/tor-project-super-secure-anonymity-network-will- 
definitely-keep-you-safe-long-hackers-dont-breakrules/f3c793136d057593f79c006054ea198274276e97/

Manning, Brendan. 2014. Dotcom Promises Election Eve Bombshell. New Zealand Herald. Accessed February 2, 2016. http://www.nzherald.co.nz/nz/news/article.cfm?c id=1\&objectid=11294243

Moment of Truth. 2014. The Moment of Truth. Accessed January 1, 2016. https://www.youtube.com/watch?v=Pbps1EwAW-0

Morozov, Evgeny. 2014. To Save Everything Click Here. New York: Public Affairs.

One News. 2015. Dotcom Spent \$5m on Internet Party, But Can't Pay Legal Bills. Accessed February 22, 2016. https://www.tvnz.co.nz/one-news/new-zealand/dotcom-spent-5mon-internet-party-but-can-t-pay-legal-bills-q14599.html

Papacharissi, Zizi. 2015. Affective Publics. Oxford: Oxford University Press.

Phillips, Whitney. 2015. This is Why We Can't Have Nice Things. Cambridge: MIT Press.

Rushkoff, Douglas. 2014. Democracy: There's an App for That. Accessed January 15, 2016. www.rushkoff.com/shareable-com-democracy-theres-an-app-for-that/

Ryan, Sophie. 2014. Dotcom Hailed as 'Super Hero' as Internet Mana Kicks Off Campaign. New Zealand Herald. Accessed February 14, 2016.

Stoeherl, Rodrigo Ferrada and Simon Lindgren. 2014. For the Lulz: Anonymous, Aesthetics, and Affect. triple-C: Communication, Capitalism \& Critique. 12 (1): 238-264.

TEDx Talks. 2013. How Technology Can Enable Everyday Democracy. Accessed March 3 , 2016. https://www.youtube.com/watch?v=4vCL419o9U

Terranova, Tiziana. 2004. Network Culture: Politics for the Information Age. London: Pluto Press.

Trevett, Claire. 2014. He's Dotcom's Little Henchman: PM Attacks Journalist's Spy Claim. New Zealand Herald. Accessed January 27, 2016. http://www.nzherald.co.nz/nz/news/article.cfm?c id=1\&objectid=11324113

TVNZ. 2014. Dirty Start to Campaign Hurts National, Labour - Poll. Accessed February 11, 2016. http://tvnz.co.nz/vote-2014-news/dirty-start-campaign-hurts-labour-national-poll$\underline{6059069}$

Vance, Andrea. 2013. GCSB Acted Illegally on Kim Dotcom. Stuff. Accessed January 29, 2016. http://www.stuff.co.nz/national/9103159/GCSB-acted-illegally-on-Kim-Dotcom

Žižek, Slavoj. 1997. The Plague of Fantasies. London: Verso.

Žižek, Slavoj. 2006. Against the Populist Temptation. Critical Enquiry 32 (3): 551-574.

Žižek, Slavoj. 2008. In Defence of Lost Causes. London: Verso.

\section{About the Author}

Olivier Jutel

A former media worker and current broadcast journalism lecturer at the University of the South Pacific in Fiji, Olivier Jutel's research is concerned with populism, psychoanalysis, affect, social media and critical theory. 